\title{
Paradoksal virkning av kunstige søtningsmidler
}

\author{
Mange bruker kunstige søtnings- \\ midler for å unngå vektøkning \\ eller for å gå ned i vekt, men kan \\ dermed øke risikoen for å utvikle \\ metabolsk syndrom.
}



Illustrasjonsfoto: NTB scanpix
Kalorifrie, kunstige søtningsmidler som sakkarin, sukralose eller aspartam er blant de mest brukte tilsetningsstoffene i mat. De brukes i slankedietter, men kan virke mot sin hensikt. Endringer i tarmens mikrobiom kan være en forklaring.

I en nylig publisert studie utviklet mus som fikk sakkarin og andre kunstige søtningsmidler i drikkevannet, etter kort tid glukoseintoleranse (1). Glukoseintoleransen ble borte etter behandling med antibiotika mot gramnegative og -positive bakterier. Bakteriefloraen i tarmen ble forandret av sakkarin, og transplantasjon av avføring til tarmen hos mikrobefrie mus gjorde også disse glukoseintolerante.

Hos 381 personer uten diabetes, hvorav noen var langtidsbrukere av kunstige søtningsmidler, fant man positiv korrelasjon mellom inntak av søtningsmidler og markører for metabolsk syndrom, slik som sentral fedme, fastende blodsukker, glukoseintoleranse og glykert hemoglobin. Det var avvik i tarmfloraen tilsvarende dem hos mus.

Fire av sju forsøkspersoner som ble satt på store doser sakkarin i sju dager, fikk både for- verret glukosetoleranse og endret tarmflora. De tre siste var ikke-respondere. Avføring fra de fire responderne ble overført til bakteriefrie mus, som da fikk de samme effektene som hos menneskene.

- Denne studien føyer seg inn i en lang rekke studier som viser en sammenheng mellom endret mikrobiota i tarm og risiko for type 2-diabetes, sier professor Harald Carlsen ved Institutt for kjemi, bioteknologi og matvitenskap ved Norges miljø- og biovitenskapelige universitet. - Det er likevel uklart hvordan sakkarin gjør dette. Funnene virker svært robuste, men jeg vil gjerne se at andre laboratorier reproduserer dem, siden resultatene kan ha stor innvirkning på vårt syn på kunstige søtningsmidler, sier Carlsen.

\section{Haakon B. Benestad}

h.b.benestad@medisin.uio.no

Universitetet i Oslo

\section{Litteratur}

1. Suez J, Korem T, Zeevi D et al. Artificial sweeteners induce glucose intolerance by altering the gut microbiota. Nature 2014; 514: $181-6$.

\section{$\emptyset$ kt risiko for kognitiv svekkelse ved diabetes}

\author{
Middelaldrende personer med type 2-diabetes har økt risiko for kognitiv \\ svekkelse i løpet av en 20 -årsperiode, ifølge en studie fra USA.
}

Type 2-diabetes er forbundet med risiko for demens, men sammenhengen mellom diabetes og kognitiv svekkelse er mindre klarlagt. En slik mulig sammenheng ble undersøkt $\mathrm{i}$ en prospektiv kohortstudie av over 13300 personer i USA i alderen 48-67 år (1).

Diabetes ble fastslått ved selvrapportert diagnose fra lege, legemiddelbruk eller $\mathrm{HbA}_{1 \mathrm{c}} \geq 6,5 \%$. Gruppen med diabetes hadde $19 \%$ større kognitiv svekkelse i løpet av 20 år enn gruppen uten diabetes. Reduksjon i kognitiv kapasitet var større hos personer med dårlig regulert diabetes $\left(\mathrm{HbA}_{1 \mathrm{c}} \geq 7,0 \%\right)$ enn hos gruppen med god kontroll. Dette var også tilfellet med personer med $\mathrm{HbA}_{1 \mathrm{c}}$ $5,7-6,4 \%$ sammenliknet med dem med lavere verdier. Varigheten av diabetes påvirket risiko for kognitiv svekkelse.

Funnene er viktige og interessante, sier professor Kåre I. Birkeland ved Avdeling for endokrinologi, sykelig overvekt og forebyggende medisin ved Oslo universitetssyke- hus. At allerede lett forhøyet blodglukose er assosiert med reduksjon i kognitiv kapasitet, understreker viktigheten av livsstilsbasert forebygging av type 2-diabetes.

Svakheter ved undersøkelsen, i tillegg til risiko for restkonfundering ved slike observasjonelle studier, er at den baserer seg på en enkeltmåling av $\mathrm{HbA}_{1 \mathrm{c}}$ ved start av observasjonsperioden og at den differensierer lite mellom $\mathrm{HbA}_{1 \mathrm{c}}$-nivåer ved etablert diabetes. Det vil være svært relevant for praktisk klinisk diabetesbehandling å vite om pasienter med $\mathrm{HbA}_{1 \mathrm{c}}$ på 7-tallet kommer bedre ut enn de med verdier over $9 \%$, sier Birkeland.

\section{Trine B. Haugen}

Tidsskriftet

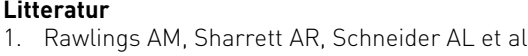
Diabetes in midlife and cognitive change over 20 years: a cohort study. Ann Intern Med 2014; 161: 785-93.
}

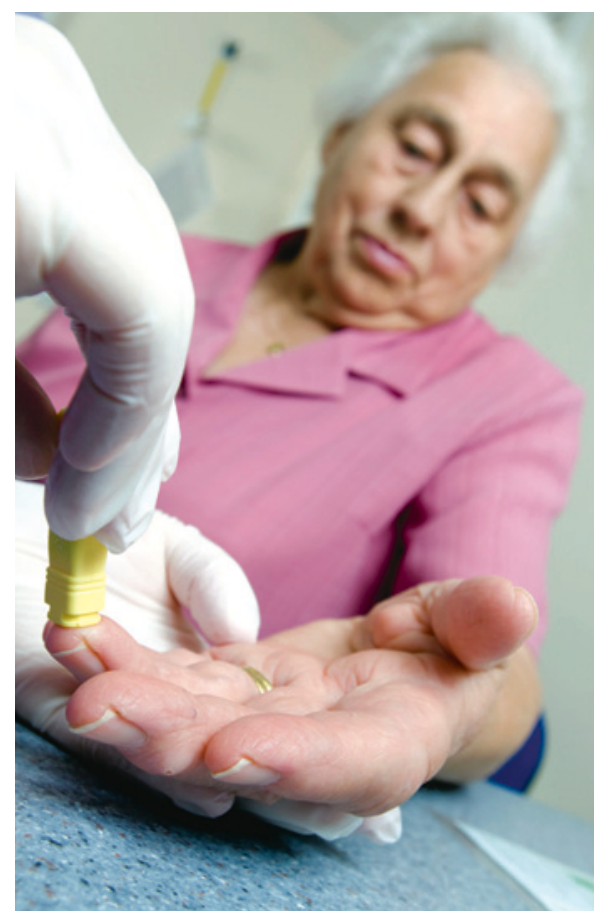

Illustrasjonsfoto: Science Photo Library 